\title{
Audio Visual Technology: Exploring The Meaning And Relevance Of Naek Dango Rituals With Sastra Nusantara Learning
}

\author{
${ }^{1}$ Herlina, ${ }^{2}$ Andayani, ${ }^{3}$ Herman J. Waluyo, ${ }^{4}$ Budhi Setiawan \\ 1alif.alifah7810@gmail.com, ${ }^{2}$ bu_anda09@yahoo.co.id, ${ }^{3}$ herman.jwaluyo@yahoo.co.id, \\ buset.74@gmail.com
}

University Sebelas Maret Surakarta, Indonesia

\begin{abstract}
This research describes how the audio-visual media is utilized in Sastra Nusantara learning especially in West Borneo. The background of this research is the learners' low interest and appreciation towards Sastra Nusantara learning. By using qualitative descriptive method, the researchers aim to design a learning scenario involving audio-visual media. It is expected that the design can be reference or alternative used by educators so that the learning process done by learners is more meaningful and attractive. To involve technology in the teaching and learning process, educators should design a learning scenario in such a way so that it is acceptable and noteworthy. Moreover, educators should involve all learners in utilizing the technology. The finding of the research shows that the utilization of audio-visual media improves learners' motivation. They concentrate more in doing the individual tasks and become more persistent in completing the tasks.
\end{abstract}

Keywords: the utilization of audio-visual technology; significance; relevance; naek dango; and sastra nusantara learning

\section{Introduction}

The solution to the various problems in literature learning has not been found until now that literature learning is desirable and even appreciated. Among the literature researchers themselves, this problem has become a homework that is still being pursued. According to Warsiman, the learning process up to now has been carried out in various boring activities [1], while according to Andayani[2], literature appreciation for some learners is difficult to be understood and uninteresting. The constraints of literature learning are also seen when learners faced with literary texts. To overcome this problem, according to Yunus[3], et al, literature learning can utilize visual aids such as graphics, images, audio, and video.

In the context of this research, the researchers believe that by utilizing audio-visual technology, literature learning can foster learners' interest and result in better learning outcomes. In line with Sadeck and Cronjé's[4] description, there is no evidence proving that teaching with technology has a washback effect on personal work. This indicates a belief, that by using technology, learning can be more successful in achieving the expected learning objectives. Therefore, the researchers are motivated to conduct this research as an alternative of the choice of teaching methods in literature learning.

Naek Dango ritual preserved by Dayak people in West Borneo is done annually in many regions even in capital region of West Borneo. Dinata[5] states that the aim of this ritual is to show gratitude towards God's (Jubata) gift and to pray for good harvest in the year to come. This ritual is done by involving various symbols (offerings). Some of the ritual steps have different intention. Naek Dango ritual is one of the forms of folklore preserved up until 
now since it is related to people's belief. Moreover, it comprises folk dance and uses symbols related to traditional food[6]. Through this research, the researchers try to utilize audio-visual technology to generate learners' logic or reasonable thinking so that the symbolism and relevance of the ritual are revealed through Sastra Nusantara learning.

\section{Literature Review}

\section{The Use of Technology in Learning}

Audio-visual technology is a way to produce or deliver materials using mechanical and electronic machines to present audio and visual messages Purwono[7], et al. According to Wicaksono[8], the use of audio visual media in learning can arouse curiosity and bring up very interesting ideas in the learners' mind, generating motivation and stimulation as well as influencing learners' psychology.

In the field, only a few teachers routinely use computers for learning objectives in different subjects such as science, mathematics, language, trade, social sciences, etc. When computers are used, they are generally used for low-level tasks such as presentations, word processing carried out on elementary-, middle-, and upper-middle-class learners Bhalla[9], whereas the use of technology is believed to be able to change the teaching and learning process to be more student-centred, improve learning outcomes, create, and enable opportunities in developing creativity, problem-solving skills, information-reasoning skills, and communication skills Tonui and Koross[10], In learning, as explained by Warner[11] et al., technology can add significantly to the quality of learners' learning experiences if used as a tool to solve their learning problems, whereas according to Adebisi[12], the current learning environment with various technologies creates new options to make a difference in instruction and supports the participation of all learners, even including those with learning difficulties. Even with technology, teachers can help to maintain learners' interests and excitement to provide a variety of instructional techniques and presentations in the classroom Inoue and Bell[13].

\section{Sastra Nusantara Learning in West Borneo}

Sastra Nusantara is one of some subjects in IKIP PGRI Pontianak where the researcher lectures. This subject is learned so that the learners know various literatures in Indonesia. Thus, diverse learning materials related to forms and types of Sastra Nusantara are given. Looking at the learning resource used by the lecturer of Sastra Nusantara enclosed in the lesson plan, local literature is forgotten. Therefore, the researchers select Naek Dango ritual so that it motivates lecturers to choose local literature as teaching material. Related to the selection of local folklore based on Laurillard's[14] description, learners should learn in a condition that they can relate their prior knowledge and experience in a certain context.

Besides the reference used that ignores local context, the teaching learning scenario planned by the lecturer is monotonous even though projector that can be used to make the teaching learning process varies is available (lesson plan enclosed). This is seen as an inappropriate way since undergraduates nowadays live along with rapid digital development. They tend to fond of something that involves both visual and audio. Hence, learning will be more interesting and motivating if audio-visual technology is utilized.

\section{Research Methodology}


This research applied descriptive-qualitative method, by looking at the motivation shown by the learners when attending the lecture of Sastra Nusantara. The data were collected by observing two meetings. In the first meeting, the lecturer applied the conventional learning method while in the second meeting, he used audio-visual technology. To see the level of the learners' motivation, the researchers observed their motivation in following the learning process of Sastra Nusantara. The indicators related to the motivation are (1) diligently facing the task, (2) being resilient in facing difficulties, and (3) showing interest Sardiman[15] in Susanto[16], The participants of this research were the learners of IKIP PGRI Pontianak consisting of one class with a total of fifty learners. The purpose of this research was to describe the learners' motivation in learning Sastra Nusantara in relation to the use of audiovisual technology

\section{Findings and Discussion}

This research benefits simple mechanism that has a possibility to improve the learners' motivation since it utilizes local context and technology as the thing, they usually do such as using internet to search for any information related their tasks. In order to avoid complexity, West Borneo learners' lack of background knowledge on the utilization of technology in learning should be considered. This idea is in line with the statement of Shinsky and Stevens[17] who affirm that learning should be adjusted to suit learners' knowledge and skill. It is also supported by a research conducted by Ayao[18] who analyzes issues related to the obstacles in utilizing weblog in higher education in Philippines. In that research, Ayao explains that one of the obstacles is learners' difficulty in mastering technology.

The research is started by deciding the research procedures to utilize audio-visual technology in Sastra Nusantara learning. First, the objective of utilizing technology is determined. In this research, the objective is to guide the learners in analyzing Naek Dango ritual to find its significance and relevance towards Sastra Nusantara learning. In doing the analysis, the learners have autonomy. In terms of Sastra Nusantara learning relevance, the researchers explain first the relevance that they should find.

In the actual practice, the researchers in this step show how Naek Dango ritual is performed. The learners are asked to watch the steps of Naek Dango ritual. With the table given, they note any possibilities related to the context that may explain the significance of the ritual. As it is related to ritual, it is suggested that the learners note the location, estimated time, participants involved (analyzed based on various aspects such as their estimated age and roles in performing the ritual) and others.

Second, after the learners fill the data on the table; they are asked to watch the video again. However, they do not watch the full version of the video. They watch only the cut scenes. This is done so that the learners try to remember and make logic sequences of the ritual. By doing so, they have deeper analyzed and finally find the significance of Naek Dango ritual. In this step, the learners should refer to the note they make. They are also asked to search any supportive data on the significance of the ritual by utilizing document on the internet or YouTube. The implicit objective of this step is to make the learners able to relate the significance they find with the underlying context. The same thing is also discussed by Abykanova[19] et.al in their research find that the utilization of technology in learning offers reasoning autonomy as long as learners have full responsibility on what they. That research illustrates the practical technology utilization in learning and its effectiveness. Meanwhile, in this research, the researcher tries to design learning that involves technology.

The same idea is also described in a research conducted by Twum[20] When learners join the teaching learning process, some of them listen to audio clip and watch video clip to 
support their learning. They also use smartphones while doing a task related to certain research. Meanwhile, some of the learners use their smartphones to read scientific news, book, and article online. The difference with this research is that Twum discusses the use of technology in science learning whereas this research discusses the use of technology in Sastra Nusantara learning. In Twum' research, there is no explanation on how the technology is utilized. Based on a survey, Twum states that the utilization of smartphone improves higher education science learning in Ghana.

Third, after the second step is conducted; the learners start analyzing the relevance of their analysis on Sastra Nusantara learning. In this step, the relevance is related to learning objective on the Indonesian Qualification Framework (IQF)-based curriculum. In the presidential regulation[21] about IQF, it is described that learning objective is a competence obtained from the internalization of knowledge, attitude, skill, and experience. Meanwhile IQF is described by Musfah[22] as qualification framework that places, equalizes, and integrates education and training sector in order that job competency and position are approved in various sectors.

This research notices the relevance with attitude aspect covering a. Devoting God; b. Having good morality, ethics, and personality in completing the task; c. Being citizen who proud of and love his/her homeland and supporting peace; d. Being able to cooperate and having good social sensitivity and care towards others and surrounding; e. Respecting the diversity of cultures, points of view, beliefs, religions, and others' ideas/inventions; f. Enforcing the law and prioritizing others' interest. In this step, as it is related to attitude, learners are asked to watch the video again. They analyze once more the significance that they find by searching or referring to various internet sources. Therefore, they have more knowledge on Dayak people's tradition in West Borneo. The sources that learners refer can be folklore, other ritual, blog, research report, and other sources.

\section{Learners' Motivation}

On the second meeting, the lecturer who teaches Sastra Nusantara implements conventional method which is lecturing. The lecture tells how Naek Dango ritual is performed along with its purpose and tells about Nek Baruakng Kulub as folklore believed to be the origin of rice in their life and how rice is respected. Moreover, the lecturer also explains the offerings involved. While the lecturer explains, learners are asked to take important note in order that they can complete the needed data related to the significance and relevance of their findings towards Sastra Nusantara learning.

After ten minutes, researchers then observe the learners' attitude. Some of them show the sign of boredom. It is indicated by their expression showing that they lost concentration. They seem to be sleepy. Some of the learners only listen to the explanation without taking note. Only few of them focus on the lecturer while taking note. Once the learners come to the process when they have to do the task to find the significance and relevance; less than fifteen learners are persistent while most of the learners show no interest on the task. This can be observed by watching the researchers' video recording. Those persistent learners focus on what they are doing. Sometimes, they communicate with their tablemate to discuss the information they do not comprehend yet. Meanwhile, other thirty-five learners seem to do their task but they do not take it seriously. They often check their tablemates' work and look sleepier. Moreover, they even only scribble their books.

On the second meeting, the lecture is equipped with audio-visual technology. The researchers' find through the observation that, in this meeting, most of the learners show interest on the video played. This is indicated by the learners' focus. They pay more attention. 
Even from fifteen learners who once are unmotivated on the first meeting watch the video enthusiastically. The learners' attitude is different from the first meeting. At the time when they should do the task, most of the learners concentrate on their work. They have better focus on the task they are doing. The frequency of checking the tablemate's work is lessened even though some learners still do it. The most remarkable thing is that no students scribble on their books. All learners do the same thing which is conveying their ideas into written work.

\section{Conclusion}

Based on the researchers' observation on the first and second meeting, it is clear that audio-visual technology has positive influence towards the learners. It is indicated by the improvement on learners' motivation. The higher motivation makes the learners to be more focus and concentrated on their individual task. They also become more persistent in completing the task.

\section{References}

[1] Warsiman, Membumikan Pembelajaran Sastra yang Humanis. Malang: UB Press, 2016.

[2] Andayani, Problema dan Aksioma: Dalam Metodologi Pembelajaran Bahasa Indonesia. Yogyakarta: Deepublish, 2015.

[3] D. Yunus, Melor Md, "Using Visual Aids as a Motivational Tool in Enhancing Students Interest in Reading Literary Texts," in Recent Advances in Educational Technologies, 2013, pp. 144-177.

[4] J. Sadeck, Osman dan Cronjé, "A Continuum of Teachers' e-Learning Practices," Electron. J. e-Learning, vol. 2, no. 2, pp. 395-408, 2017.

[5] A. Dinata, Rumah Sehat Jubata, Radang. Jakarta: Lembaga Penerbitan Balitbangkes, 2014.

[6] S. Endraswara, Metodologi Penelitian Folklor. Yogyakarta: MedPress, 2009.

[7] D. Purwono, Joni, "Penggunaan Media Audio-Visual Pada Mata Pelajaran Ilmu Pengetahuan Alam Di Sekolah Menengah Pertama Negeri 1 Pacitan,” J. Teknol. Pendidik. Dan Pembelajaran, vol. 2, no. 2, pp. 127-144, 2014.

[8] A. Wicaksono, Menulis Kreatif Sastra dan Beberapa Model Pembelajarannya. Yogyakarta: Garudhawacana, 2014.

[9] J. Bhalla, "Computer Use by School Teachers in Teaching-learning Process," J. Educ. Train. Stud., vol. 1, no. 2, pp. 174-185, 2013.

[10] E. K. R. Tonui, Betty dan Koross, "An Investigation into Implementation of ICT in Primary Schools, in Kenya, in the Light of Free Laptops at Primary One A Case Study of Teachers Implementing ICT into Their Teaching Practice," J. Educ. Pract., vol. 7, no. 13, pp. 12-16, 2016.

[11] D. Warner, Connor K, "Defining Technology for Learning: Cognitive and Physical Tools of Inquiry," Middle Grades Rev., vol. 4, no. 1, pp. 1-9, 2018.

[12] D. Adebisi, Rufus Olanrewaju, "Using Assistive Technology in Teaching Children with Learning Disabilities in the 21 st Century," J. Educ. Pract., vol. 6, no. 24, pp. 14 20, 2015.

[13] S. T. Inoue, Yukiko dan Bell, Teaching with Educational Technology in the 21 st Century: The Case of the Asia-Pacific Region. Amerika: London: Routledge Falme, 2006.

[14] D. Laurillard, Rethinking University Teaching 2nd Edition: A conversational 
framework for the effective use of learning technologies, 2nd ed. 2002.

[15] sardiman; "Interaksi \&amp; Motivasi Belajar Mengajar," 2011.

[16] A. Susanto, Bimbingan dan Konseling di Sekolah: Konsep, Teori, dan Aplikasinya. Jakarta: Prenadamedia Group, 2018.

[17] H. A. Shinsky, E John dan Stevens, "Teaching in Educational Leadership Using Web 2.0 Applications: Perspectives on What Works," J. Res. Leadersh. Educ., vol. 6, no. 5, pp. 197-215, 2011.

[18] S. Ayao, "Emerging Issues in the Utilization of Weblogs in Higher Education Classrooms," Int. J. Teach. Learn. High. Educ., vol. 26, no. 2, pp. 193-204, 2014.

[19] D. Abykanova, Bakytgul, "The Use of Interactive Learning Technology in Institutions of Higher Learning," Int. J. Environ. Sci. Educ., vol. 11, no. 18, pp. 12528-12539, 2016.

[20] R. Twum, "Utilization of Smartphones in Science Teaching and Learning in Selected Universities in Ghana," J. Educ. Pract., vol. 8, no. 7, pp. 216-228, 2017.

[21] Peraturan Presiden Republik Indonesia Nomor 8 Tahun 2012 Tentang Kerangka Kualifikasi Nasional Indonesia. Indonesia, 2012.

[22] J. Musfah, Analisis Kebijakan Pendidikan: Pendidikan Nirkreasi. Jakarta: Prenadamedia Group, 2016. 